virus RNA level is associated with hepatitis $B$ virus genotype and BCP mutations in untreated patients with $\mathrm{HBeAg}$ positive chronic hepatitis B", Journal of hepatology. 66(1), S253-S254.

7. Jennings $L$, Van Deerlin VM, Gulley ML.2009.Recommended principles and practices for validatingclinical molecular pathology tests. Arch Pathol Lab Med.133(5):743-755.

8. J. Wang, T. Shen, X. Huang et al., (2016), "Serum hepatitis B virus RNA is encapsidated pregenome RNA that may be associated with persistence of viral infection and rebound", J Hepatol. 65(4), 700-10.

\title{
NGHIÊN CỨU ĐĂC ĐIỂM LÂM SÀNG VÀ KẾT QUẢ ĐIỀU TRI BÊ̂NH THỦY ĐÂUU BẰNG ZINCPASTE TẠI PHÒNG KHÁM CHUYÊN KHOA DA LIỄU FOB CẦN THO' NĂM 2020-2021
}

\author{
Trần Ngọc Sĩ***, Huỳnh Như Huỳnh*, Nguyễn Văn Nguyên**, \\ Nguyễn Thị Thúy Liễu*, Hà Thị Thảo Mai*, Huỳnh Văn Bá*
}

\section{TÓM TẮT}

Muc tiêu: Nghiên cứu đăc điểm lâm sàng và kết quả điều trị bệnh thủy đậu bằng Zincpaste tại Phòng khám chuyền khoa Da liểu FOB Cần Thơ năm 20202021. Đối tượng và phương pháp: Phương pháp nghiên hàng loạt ca trên 60 bênh nhân mắc bênh thủy đậu điều trị ngoại trú tại Phòng khám Da liểu FOB Cân Thơ năm 2020 - 2021. Kết quả: Nhóm tuổi 20-39 tuổi thường gặp nhất $(67,24 \%)$, tỉ lệ thấp nhất là nhóm 6 tháng - 5 tuổi $(3,45 \%)$, chưa ghi nhận được nhóm $<6$ tháng tuổi và nhóm > 60 tuổi. Có tiền sử tiếp xúc với người mắc thủy đậu trước đó chiếm tỷ lệ cao $(44,83 \%)$, thấp nhất là nhóm không xác định được $(15,52 \%)$. Nhóm chưa chủng ngừa chiếm tỷ lệ cao nhất $(50 \%)$, thấp nhất là nhóm chủng ngừa không đúng $(1,72 \%)$. Triệu chứng cơ năng ngứa chiếm tỷ lể cao nhất $(75,86 \%)$. Triêu chứng toàn thân: sốt chiếm tỷ lệ cao nhất $(70,69 \%)$, kế đến là nhóm mêt mỏi $(55,17 \%)$. Thương tổn cơ bản: nhóm mụn nước, mụn nước rốn lõm chiếm tỷ lệ cao nhất $(98,28 \%)$, thấp nhất là nhóm sẹo $(1,72 \%)$. Vị trí sang thương gặp ở thân minh chiếm tỷ lệ cao nhất $(98,28 \%)$. Sau 5 ngày, có $67,24 \%$ bênh đáp ứng tốt, $32,76 \%$ đáp ứng khá. Sau 10 ngày, có $82,76 \%$ bệnh đáp ứng tốt, $17,24 \%$ đáp ứng khá. Sau 15 ngày, $100 \%$ bệnh nhân đáp ứng tốt. Số lần thoa thuốc $\geq 2$ lần cho đáp ứng điều trị tốt hơn thoa <2 lần/ngày, mối tương quan này có ý nghĩa thống kê. Qua các tuần điều trị không ghi nhận bất kì tác dụng không mong muốn nào. Kết luân: Bệnh cải thiện dần trong quá trình điều trị, người bệnh nên tuân thủ phát đồ điều trị theo bác sĩ chuyên khoa hướng dẫn để đạt kết quả tốt và tránh các biến chứng. Đáp ứng điều trị có liên quan đến số lần sử dụng thuốc bôi tại chỗ, cần tư vấn bệnh nhân sử dụng thuốc bôi $\geq 2$ lần/ngày để đạt được hiệu quả tốt nhất. Ghi nhận Zincpaste cho kểt

*Trường Đai hoc Y Dược Cần Tho **TT GD Nghể nghiêp Thẩm mỹ FOB

***Viên Thẩm mỹ Quốc Tế $A$ \&A

Chịu trách nhiệm chính: Huỳnh Văn Bá

Email: bs.ba fob@yahoo.com.vn

Ngày nhận bài: 29/4/2021

Ngày phản biên khoa hoc: 20/5/2021

Ngày duyệt bài: 18/6/2021 quả tốt trong điều trị thủy đậu, thuốc bôi tại chỗ không ghi nhận tác dụng phụ.

Tư khóa: Bệnh thủy đậu, đặc điểm lâm sàng, kết quả điều trị, Zinspate.

\section{SUMMARY \\ RESEARCH ON MANIFESTAION AND OUTCOMES OF CHICKEN POX WITH ZINCPASTE AT FOB DERMATOLOGY CLINIC IN 2020-2021}

Objectives: Studying clinical characteristics and treatment results of chickenpox with Zincpaste at FOB Can Tho Dermatology Clinic in 2020-2021. Subjects and methods: Series cases study on 60 outpatients with chickenpox at FOB Dermatology Clinic in 20202021. Results: The most common age group is 20-39 year-old group $(67,24 \%)$, the lowest rate was in the group of 6 months - 5 years old patient (3.45\%), there is no patient in the $<6$ month-old group and the $>60$ years old group. Having a history of contacting people with chickenpox previously accounted for a highest rate $(44.83 \%)$, the lowest rate was in unidentified group $(15.52 \%)$. The unvaccinated group accounted for the highest percentage $(50 \%)$, the lowest percentage was in the incorrect vaccination group (1.72\%). Symptoms of itching accounted for the highest percentage $(75.86 \%)$. Systemic symptoms: fever accounted for the highest rate $(70.69 \%)$, followed by fatigue $(55.17 \%)$. Basic lesions: the group of blisters, umbilical vesicles accounted for the highest rate $(98.28 \%)$, the lowest rate was in the scar group $(1.72 \%)$. Lesions found in the trunk accounted for the highest percentage $(98.28 \%)$. After 5 days, $67.24 \%$ of patients had excellent reponse, $32.76 \%$ had fare reponse. After 10 days, $82.76 \%$ of patients had excellent reponse, $17.24 \%$ had fare reponse. After 15 days, $100 \%$ of patients had excellent reponse. The number of times of applying the drug: patients applying it $\geq 2$ times/day gave a better treatment response than those applying it $<2$ times/day. This correlation is statistically significant. After the course of treatment with with Zincpaste gave excellent treatment results Conclusion: The severity of the disease improves gradually during the course of treatment, the patient should adhere to the treatment regimen as instructed 
by the specialist to achieve excellent outcomes and avoid possible complications. Treatment response is related to the number of times of using topical drugs. It is necessary to advise patients to use topical drugs $>2$ times/day to achieve the best effect. The results showed that Zincpaste gave excellent results as a therapy for chickenpox. Consequently, it is possible to consider adding Zincpaste to widely usage in the treatment guildline for chickenpox. There is no side effect recorded for topical therapy.

Keywords: Chickenpox, clinical features, treatment results, Zinspate.

\section{I. ĐĂT VẤN ĐỀ}

Thuỷ đậu là bệnh có nguy cơ lây nhiễm cao, gây nên bởi Herpesviruses Varicellae, còn gọi là Varicella-zoster virus (VZV). Đại đa số bệnh nhân là trẻ từ 2-10 tuổi. Tuy nhiên, gần đây có nhiều thanh thiếu niên và người trưởng thành cũng mắc bệnh này, đó là nhiễm virus sơ phát ở những người dể cảm thụ với virus thuỷ đậu. Khả năng nhiễm bệnh những người chưa có miễn dịch khi tiếp xúc với bệnh nhân thuỷ đậu là khoảng $90 \%$. Bệnh nhân thường có tiên triệu thời gian ngắn trước khi xuất hiện cảc thương tổn nhưng có khi không có biểu hiện gì. Tiền triệu thường là cảc biểu hiên viêm lồng đường hô hẩp hoặc biểu hiện như cúm. Biểu hiện ngoài da ban đầu là các ban ngứa hoặc các sẩn rồi nhanh chóng chuyển thành mụn nước, mụn mủ và đóng vẩy tiết. Trẻ khoẻ mạnh các triêuu chứng toàn thân thường nhẹ và cảc biến chứng nặng rất hiểm xảy ra [3], [4], [5]. Thủy đậu là một bênh phổ biến trên toàn cầu, $95 \%$ người trưởng thành có huyết thanh dương tính. Ớ các nước ôn đới, $90 \%$ các ca bệnh là trẻ em dưới 10 tuổi, bênh nhân lớn hơn 15 tuổi chỉ chiếm dưới $5 \%$ trong khi các vùng nhiệt đới và cận nhiệt đới, độ tuổi trung bình mắc thủy đậu lớn hơn [3]. Bệnh thủy đậu sau điều trị có thể để lại sẹo nếu sang thương bị nhiễm trùng, cho nên việc điều trị kịp thời và sử dụng các thuốc bôi tại chỗ lên các sang thương mụn nước cũng góp phần quan trọng trong việc lành các sang thương hạn chế seoo. Chính vì vây, chúng tôi thực hiện đề tài nghiên cứu "Nghiên cứu đặc điểm lâm sàng và kết quả điều trị bệnh thủy đậu bằng Zincpaste tại Phòng khám chuyên khoa Da liễu FOB Cần Thơ năm 2020 - 2021" với hai mục tiêu:

- Mô tả đặc điểm lâm sàng bệnh thưy đậu những bệnh nhân đến khám và điều trí.

- Đánh giá kêt quả điều trị bệnh thủy đậu bằng Zincpaste.

II. ĐỐI TƯợNG VÀ PHƯƠNG PHÁP NGHIÊN CứU

1. Đối tượng nghiên cứu: 60 bệnh nhân được chẩn đoán xác định bệnh thủy đậu, điều trị tại
Phòng khám Da liễu FOB Cần Thơ năm 2020- 2021.

Tiêu chuẩn chọn:

- Tiêu chuẩn chẩn đoán: dựa vào lâm sàng

- Bệnh nhân đồng ý tham gia nghiên cứu.

Tiêu chuẩn loại trừ: Bệnh nhân mắc các bệnh lí tâm thần. Bệnh nhân không đồng ý tham gia nghiên cứu. Bệnh nhân có bệnh lí tim mạch nặng, suy gan, suy thận..

\section{Phương pháp nghiên cứu}

Thiết kế nghiên cứu: Mô tả hàng loạt ca

Vật liệu nghiên cứu: Zincpaste

- Thành phần: Zinc oxide, Titan dioxide, Glycerin, Gluconolactone, nước tinh khiết vừa đủ.

- Công dụng: Chăm sóc rôm sảy, hăm kẽ, thủy đậu, làm khô các tổn thương rỉ dịch

- Cách sử dụng: Thoa ngày 2-3 lần trên vùng da có nhu cầu

TC: 071.027.15; SPTN: 031/16/CBMP-CT

- Đơn vị sản xuất: công ty TNHH mỹ phẩm Hồng Nhung

- Địa chỉ: 14/14 Lý Tự Trọng, P. An Cứ, Q. Ninh Kiêu, TP. Cần Thơ.

- Thời gian theo dõi kết quả điều trị: 5 ngày, 10 ngày, 15 ngày.

\section{KẾT QUẢ NGHIÊN CứU}

Có 60 đối tượng tham gia nghiên cứu từ 2020-2021

\section{Tuổi của đối tượng nghiên cứu}

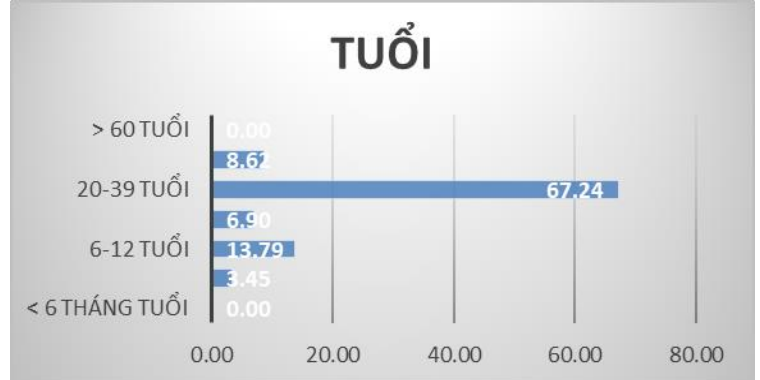

Nhận xét: Nhóm tuổi 20-39 tuổi thường gặp nhất $(67,24 \%)$, tỉ lệ thấp nhất là nhóm 6 tháng 5 tuổi $(3,45 \%)$. Chưa ghi nhận được nhóm < 6 tháng tuổi và nhóm > 60 tuổi.

\section{Tiên sử tiếp xúc với người mắc thủy đậu}
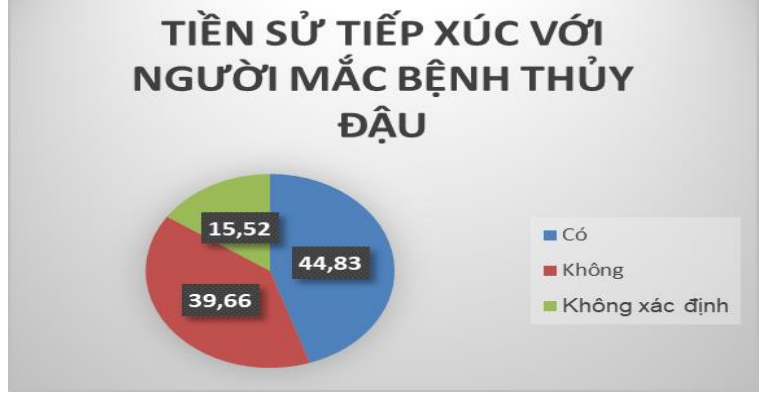
Nhận xét: Tỷ lệ cao nhất là có tiền sử tiếp xúc với người mắc thủy đậu trước đó $(44,83 \%)$

\section{Chủng ngừa thủy đậu}

\section{CHỦNG NGỪA THỦY ĐẬU}

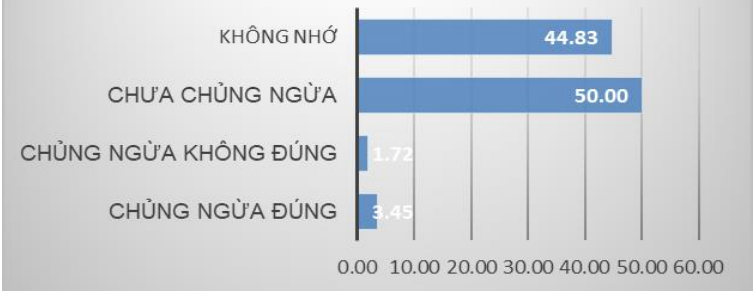

Nhận xét: Nhóm chưa chủng ngừa chiếm tỷ lệ cao nhất (50\%)

4. Kết quả điêu trị bệnh thuỷ đậu

- Kết quả điêuu trị. Sau 5 ngày, có $67,24 \%$ bệnh đáp ứng tốt, 32,76\% đáp ứng khá. Sau 10 ngày, có $82,76 \%$ bệnh đáp ứng tốt, $17,24 \%$ đáp ứng khá. Sau 15 ngày, 100\% bệnh nhân đáp ứng tốt.

\section{Triệu chứng cơ năng}

\section{TRIẸU CHƯNNG CO' NĂNG}

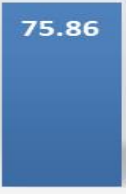

NGỨA

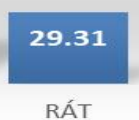

\subsection{4}

Nhận xét: Nhóm triệu chứng ngứa chiếm tỷ lệ cao nhất (75,86\%)

\section{Triệu chứng toàn thân}

\section{TRIẸU CHỨNG TOÀN THÂN}

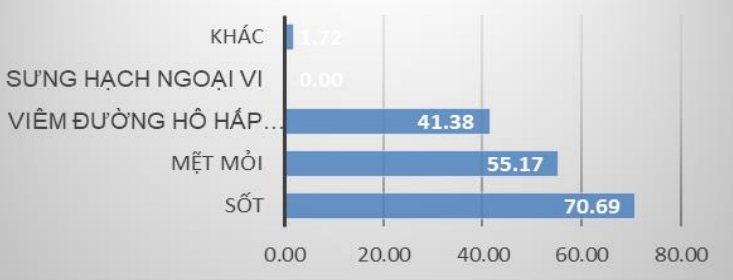

Nhận xét: Sốt chiếm tỷ lệ cao nhất (70,69\%) 7. Thương tổn cơ bản

THƯƠNG TỔN CƠ BẢN

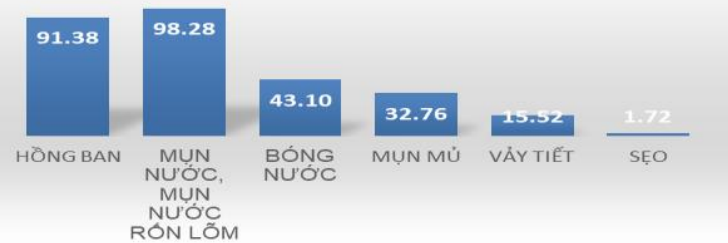

Nhận xét: Nhóm mụn nước, mụn nước rốn Iõm chiếm tỷ lê cao nhất $(98,28 \%)$

8. Vị trí tổn thương

\section{V! TRÍ TỔN THƯƠNG}

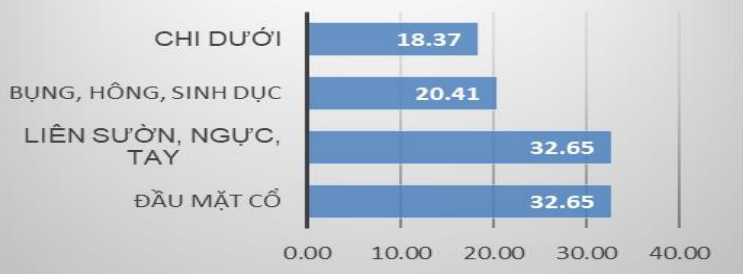

Nhận xét: Thường gặp nhất là ở thân mình $(98,28 \%)$, kế đến là đâu mặt cổ $(94,83 \%)$, ít gặp nhất là nhóm niêm mạc (29,31\%).

- Mối liên quan giữa số lân thoa thuốc và đáp ứng điêu trị

\begin{tabular}{|c|c|c|c|c|c|c|c|}
\hline \multirow{2}{*}{$\begin{array}{l}\text { Số lần thoa } \\
\text { thuốc }\end{array}$} & \multicolumn{2}{|c|}{ Đáp ứng sau 5 ngày } & \multicolumn{2}{|c|}{ Đáp ứng sau 10 ngày } & \multicolumn{2}{|c|}{ Đáp ứng sau 15 ngày } & \\
\hline & Tốt & Khá & Tốt & Khá & Tốt & Khá & \multirow{3}{*}{$\mathbf{p}<0.05$} \\
\hline <2 lần & $0,0 \%$ & $20,7 \%$ & $3,40 \%$ & $17,30 \%$ & $21,10 \%$ & $0 \%$ & \\
\hline$\geq 2$ lần & $32,80 \%$ & $46,50 \%$ & $79,30 \%$ & $0 \%$ & $78,90 \%$ & $0 \%$ & \\
\hline $\mathrm{n}$ & & & & & & & \\
\hline
\end{tabular}

Nhân xét: Kết quả nghiên cứu cho thấy số lần thoa thuốc $\geq 2$ lần cho đáp ứng điều trị tốt hơn thoa <2 lần/ngày. Mối tương quan này có ý nghĩa thống kê $(p<0.05)$.

9. Tác dung không mong muốn của thuốc

\begin{tabular}{|c|c|c|c|}
\hline Tác dụng phụ & $\mathbf{5}$ ngày & $\mathbf{1 0}$ ngày & $\mathbf{1 5}$ ngày \\
\hline Ngứa da & 1 & Không & Không \\
\hline Đỏ da & Không & Không & Không \\
\hline Nóng rát tại chồ & Không & Không & Không \\
\hline Phát ban, mày đay & Không & Không & Không \\
\hline Khác & Không & Không & Không \\
\hline
\end{tabular}

Nhận xét: chỉ ghi nhận 1 trường hợp tăng ngứa da sau 5 ngày điều trị.

\section{BÀN LUẬN}

1. Tuổi của đối tượng nghiên cứu. Nhóm tuổi 20-39 tuổi thường găp nhất $(67,24 \%)$, tỉ lệ thấp nhất là nhóm 6 tháng -5 tuổi $(3,45 \%)$. Chưa ghi nhận được nhóm < 6 tháng tuổi và nhóm > 60 tuổi. Kết quả nghiên cứu này phù hợp với kết quả nghiên cứu của Ngô Tùng (2007) ghi nhận lứa tuổi mắc bệnh chủ yếu là $>16$ tuổi $(76,5 \%)$ [1], nghiên cứu của Quách Thị 
Hà Giang (2011) cho thây bệnh gặp nhiều ở lứa tuổi 20 - 39 tuổi $(42,4 \%)$ [2], nghiên cứu của Đoàn Thu Nga (2015) cho thấy lứa tuổi 21-30 mắc bệnh nhiều nhất $(41,5 \%)$ [6].

2. Tiền sử tiếp xúc với người mắc thủy đậu. Tỷ lệ cao nhất là có tiền sử tiếp xúc với người mắc thủy đậu trước đó $(44,83 \%)$, thấp nhất là nhóm không xác định được (15,52\%). Kết quả nghiên cứu này phù hợp với kết quả nghiên cứu của Quách Thị Hà Giang ghi nhận đa số bệnh nhân có yếu tố dịch tễ (80\%) [2], nghiên cứu của Dương Văn Thanh và Lê Thị Lựu ghi nhận có 43,4 $\%$ có tiền sử tiếp xúc với nguồn lây [8].

3. Chủng ngừa thủy đậu. Nhóm chưa chủng ngừa chiếm tỷ lệ cao nhất (50\%), kế đến là nhóm không nhớ (44,83\%), thấp nhất là nhóm chủng ngừa không đúng $(1,72 \%)$. Kết quả này tương đông với kết quả nghiên cứu của Quách Thị Hà Giang ghi nhận chỉ có $16,9 \%$ bệnh nhân đã được tiêm chủng vaccin thủy đậu nhưng vẫn mắc lại bệnh [2], nghiên cứu của Đặng Lê Như Nguyệ ghi nhận chỉ có 5 bệnh nhân đã được chủng ngừa thủy đậu [7], nghiên cứu của Dương Văn Thanh và Lê Thị Lựu ghi nhận không có bệnh nhân được tiêm vaccine phòng bệnh thủy đậu [8].

4. Triệu chứng cơ năng. Nhóm triệu chứng ngứa chiểm tỷ lệ cao nhất $(75,86 \%)$, kế đến là nhóm triệu chứng rát $(29,31 \%)$, thấp nhất là nhóm đau (24,14\%). Kết quả này không phù hợp với nghiên cứu của Ngô Tùng Dương ghi nhận triệu chứng ngứa $(59,36 \%)$ và rát $(37 \%)$ [1], nghiên cứu của Quách Thị Hà Giang ghi nhận hầu hết các trường hợp đều có ngứa (97\%) [2].

5. Triệu chứng toàn thân. Nhóm sốt chiếm tỷ lệ cao nhất (70,69\%), kế đến là nhóm mệt mỏi $(55,17 \%)$, thấp nhất là nhóm triệu chứng khác $(1,72 \%)$. Không ghi nhận trường hợp bị sưng hạch ngoại vi. Kết quả này tương đồng với kết quả nghiển cứu của Ngô Tùng Dương ghi nhận viêm lông đường hô hấp $(97,5 \%)$, sốt $(77,8 \%)$, hạch sưng đau $(35,8 \%)$ [1], nghiên cứu của Dương Văn Thanh và Lê Thị Lựu ghi nhận hầu hết bệnh nhân có biểu hiện sốt $(98,7 \%)$ [8].

6. Thương tổn cơ bản. Nhóm mụn nước, mụn nước rốn lõm chiếm tỷ lệ cao nhất (98,28\%), kế đến là nhóm hồng ban $(91,38 \%)$, thấp nhất là nhóm sẹo $(1,72 \%)$. Kết quả này tương đương nghiên cứu của Ngô Tùng Dương ghi nhận tất cả $B N$ có mụn nước $(100 \%)$, mụn nước lõ̉m giữa $(90,1 \%)$, hồng ban $(80,2 \%)$, mụn mủ $(82,7 \%)$, vảy tiết $(82,7 \%)[1]$, của tác giả Quách Thị Hà Giang ghi nhận tất cả bệnh nhân $100 \%$ có tổn thương cơ bản là mụn nước; ban đỏ là 96,9\%; các loại tổn thương khác chiếm tỉ lệ ít hơn như vết trợt $63,1 \%$, mụn mủ $15,4 \%$, vảy tiết ẩm 13,8\% [2], nghiên cứu của Đoàn Thu Nga ghi nhận tổn thương cơ bản là mụn nước $(100 \%)$, mụn nước lõm giữa $(97,7 \%)$, hồng ban $(86,2 \%)$, mụn mủ (25,5\%). Đa số bệnh nhân thuỷ đậu ở mức độ vừa $(60,6 \%)$, kế đến là mức độ nhẹ $(28,7 \%)$, mức độ nặng (10,6\%). [6].

7. Vị trí tổn thương. Thường gặp nhất là ở thân mình $(98,28 \%)$, kế đến là đầu mặt cổ $(94,83 \%)$, ít gặp nhất là nhóm niêm mạc $(29,31 \%)$. Tỉ lệ này của nghiên cứu chúng tôi tương đương tác giả Quách Thị Hà Giang ghi nhân $100 \%$ bênh nhân đều có tổn thương ở đầu, mặt, cổ và thân mình; $32,3 \%$ bệnh nhân có thương tổn ở niêm mạc [2].

8. Kết quả điều trị bệnh thuỷ đậu. Sau 5 ngày, có $67,24 \%$ bệnh đáp ứng tốt, $32,76 \%$ đáp ứng khá; sau 10 ngày, có $82,76 \%$ bệnh đáp ứng tốt, $17,24 \%$ đáp ứng khá; sau 15 ngày, $100 \%$ bệnh nhân đáp ứng tốt. Điều trị có đáp ứng, qua 5 ngày, 10 ngày, 15 ngày mức độ đáp ứng tốt ngày càng tăng. Kết quả nghiên cứu cho thấy số lân thoa thuốc $\geq 2$ lần cho đáp ứng điều trị tốt hơn thoa <2 lần/ngày. Mối tương quan này có ý nghĩa thống kê $(p<0.05)$. Điều này chứng minh được tác dụng của thuốc bôi tại chỗ trong việc làm tăng khả năng phục hồi của bệnh. Zinpaste có thành phần chủ yếu là kẽm oxide và gluconolacton. Gluconolacton (PHAs) có tác dụng kích hoạt chu kỳ đổi mới tế bào, loại đi các tế bào da chết, phục hồi lại sự mịn màng, tái tạo các tế bào da mới từ bên dưới. PHAs là một chất giữ ầm có tác dụng chống sự mất nước qua da, duy trì độ ầm, giúp cho làn da luôn mượt mà và tươi trẻ. Zinc oxide vừa có tác dụng se da, sát khuẩn, giữ ẩm, làm khô tổn thương đang rỉ dịch nung mủ. Đồng thời không tạo màu khó chịu, làm tăng sự hài lòng cho bệnh nhân.

9. Tác dụng không mong muốn của thuốc. Theo nghiên cứu của chúng tôi, ghi nhận một trường hợp có phản ứng không mong muốn là tăng ngứa tại chố sau 5 ngày điều trị và phản ứng này sau đó cũng biến mất.

\section{KẾT LUÂN}

\section{1. Đặc điểm lâm sàng}

- Bệnh thường gặp ở nhóm dưới 40 tuổi, đặc biệt là nhóm 20-39 tuổi $(67,24 \%)$

- Có tiền sử tiếp xúc với người mắc thủy đâu trước đó $(44,83 \%)$, không có $(39,66 \%)$, không xác định được (15,52\%).

- Nhóm chưa chủng ngừa chiếm tỷ lệ cao nhất $(50 \%)$, kễ đến là nhóm không nhớ $(44,83 \%)$, thấp nhất là nhóm chủng ngừa không 
đúng $(1,72 \%)$.

- Triệu chứng cơ năng: ngứa $(75,86 \%)$, rát $(29,31 \%)$, đau $(24,14 \%)$.

- Triệu chứng toàn thân: sốt $(70,69 \%)$, mệt mỏi $(55,17 \%)$, viêm đường hô hấp trên (41,38\%), triệu chứng khác $(1,72 \%)$. Không ghi nhận trường hợp bị sưng hạch ngoại vi.

- Vị trí tổn thương: Thường gặp nhất là ở thân mình $(98,28 \%)$, kế đến là đầu mặt cổ $(94,83 \%)$, ít gặp nhất là nhóm niêm mạc $(29,31 \%)$.

- Thương tổn cơ bản: Nhóm mụn nước, mụn nước rốn lõm chiếm tỷ lệ cao nhất $(98,28 \%)$, kế đến là nhóm hồng ban $(91,38 \%)$, thấp nhất là nhóm sẹo $(1,72 \%)$.

\section{Kết quả điêu tri}

- Sau 5 ngày, có $67,24 \%$ bệnh đáp ứng tốt, $32,76 \%$ đáp ứng khá. Sau 10 ngày, có $82,76 \%$ bệnh đáp ứng tốt, 17,24\% đáp ứng khá. Sau 15 ngày, $100 \%$ bệnh nhân đáp ứng tốt.

- Số lần thoa thuốc $\geq 2$ lần cho đáp ứng điều trị tốt hơn thoa $<2$ lần/ngày $(p<0.05)$.

- Ghi nhận 1 trường hợp ngứa da sau 5 ngày điều trị, mất đi sau 10, 15 ngày điều trị.

\section{TÀI LIỆU THAM KHẢO}

1. Ngố Từng Dương (2007), "Nhận xét tình hình, đặc điểm lâm sàng, cận lâm sàng và kết quả điêu trị bệnh thuỷ đậu tại Bệnh viện 103 từ 1/2004 -
6/2007", Nhận xét tình hình, đặc điểm lâm sàng, cận lâm sàng và kết quả điều trị bệnh thuỷ đậu tại Bềnh viên 103 từ 1/2004 - 6/2007, Luận án thạc sĩ y hoc, Hà Nội.

2. Quách Thi Hà Giang (2011), "Nghiên cứu đă̆c điểm lâm sàng, cận lâm sàng và hiệu quả điều trị bệnh thủy đậu bằng uống acyclovir", Luận văn bác sĩ nôii trú bênh viên, Đại hoc Y Hà Nối.

3. Nguyễn Duy Hưng (2017), "Bệnh thủy đậu", Bệnh học Da liễu (Sách đào tạo sau đại học), NXB Y học, Hà Nội, tr. 85-93.

4. Nguyê̂n Văn Kính (2011), "Bệnh thủy đâu", Bài giảng bệnh Truyền nhiếm, Nhà xuất bản Y học, Hà Nội,tr: 273-279.

5. Nguyễn Văn Mùi, Nguyễn Hoàng Tuấn, Trinh Thị Xuân Hòa (2008), "Bệnh thủy đậu", Bệnh Truyền nhiễm và Nhiệt đới, Nhà xuất bản $Y$ học, tr. 166-171.

6. Đoàn Thu Nga (2016), "Nghiên cứu đăcc điểm lâm sàng, các yếu tố liên quan và kết quả điều trị bênh thủy đậu bằng uống Acyclovir tại Bệnh viện Da liễu Cần Thơ năm 2015 - 2016", Luận văn tốt nghiệp bác sĩ đa khoa, Trường Đại học Y Dược Cần Thơ.

7. Đăng Thi Như Nguyệt, Đoàn Thi Diệp Ngọc (2010), "Đăc điểm lâm sàng bênh thủy đâu trẻ em tại bệnh viện Nhi đồng I "Tạp chí Y học Thành phố Hồ Ćhí Minh, tập 14, tr. 367-371.

8. Dương Văn Thanh, Lê Thị Lựu (2015), "Nghiên cứu đặc điểm bệnh thủy đạu ở bệnh nhân điều tri tai khoa truyền nhiễm bênh viên đa khoa trung ươnì Thái Nguyên từ $2013^{\circ}-2015^{\prime \prime}$, Tạp chí Y học Viêt Nam.

\section{MÁU TƯ DƯớI MÀNG CỨNG CẤP TÍNH: TỈ LỆ, ĐặC ĐIỂM VÀ KẾT QUẢ ĐIỀU TRI}

\section{TÓM TẮT}

Mục tiêu: Nhận xét tỉ lệ, đặc điểm lâm sàng, tổn thương trên chụp cắt lớp vi tính và kết quả điểu trị máu tư dưới màng cứng cấp tính. Phương pháp: Mồ tả cắt ngang 153 trường hợp máu tụ dưới màng cứng cấp tính điều tri tai khoa Phẫu thuât Thần kinh-Cột sống bệnh viện Đaa khoa tỉnh Thái Bình trong thời gian từ tháng 2 đến tháng 9 năm 2020. Kết quả: 153 bệnh nhân máu tụ dưới màng cứng cấp tính trong tổng số 534 bênh nhân nhâp viện, chiếm tỉ lề 28,6\%. 117 bệnh nhân nam chiếm $(77,8 \%)$, nữ chiếm (22,2\%). Tuổi nhỏ nhất: 8; tuối cao nhất: 96 ; tuổi trung bình: $55,71 \pm 19,99$. Nguyên nhân tai nạn giao thông chiếm (49,7\%); tai nạn sinh hoạt $(43,8 \%)$. Lâm sàng mức độ nhẹ chiếm $87,6 \%$; mức độ trung bình

*Trường Đại họ Y Dược Thái Bình

Chịu trách nhiệm chính: Vũ Minh Hải

Email: vuminhhai777@gmail.com

Ngày nhận bài: 10.5.2021

Ngày phản biên khoa học: 28.6.2021

Ngày duyệt bài: 5.7.2021
$8,5 \%$, chỉ có 3,9\% mức đô nặng. Điều trị nội khoa chiếm $76,5 \%$, phẫu thuật lấy máu tụ $22,9 \%$. Kết quả ra viện ổn định $89,5 \%$, di chứng nhẹ $5,9 \%$, di chứng trung bình 1,3\%. Tử vong và sống thực vật 3,3\%. Kết luân: Chấn thương sọ não máu tụ dưới màng cứng cẩp tính chiếm tỉ lệ $(28,6 \%)$. Thường gặp ở nam giới. Đa số máu tụ dưới màng cứng cấp tính do chấn thương đều được điều trị bảo tồn, với 76,5\% bênh nhân trong nghiền cứu này đạt được kết quả sớm tốt. Chỉ một tỷ lệ nhỏ bệnh nhân được điều trị bảo tồn sẽ xấu đi và cần phải phẫu thuật.

Tư khóa: máu tu dưới màng cứng cấp tính, điều trị bảo tồn máu tụ nội sọ, chấn thương sọ não.

\section{SUMMARY}

\section{ACUTE SUBDURAL HEMATOMA: RATES, CHARACTERISTICS AND TREATMENT OUTCOMES}

Objectives: To evaluate the rates, clinical characteristics, lesions on CT scan and outcomes of treatment of acute subdural hematoma. Methods: A cross-sectional descriptive study was undertaken in 153 cases of acute subdural hematoma treated at the 